\title{
'Karangwangi' Corridor Analysis as an Imaginary Axis of Cirebon City
}

\author{
Yoyon Indrayana ${ }^{1}$, Hardi Warsono ${ }^{2}$ \\ \{yo.indra@gmail.com ${ }^{1}$, hardie_wsn@yahoo.com $\left.{ }^{2}\right\}$ \\ Universitas Diponegoro, Indonesia ${ }^{1,2}$
}

\begin{abstract}
Cirebon city has experienced a long period of historical development. In that period a lot of values and historical events that took place to form the characteristics of the city that exists today. Even so the remnants of the past in the form of architectural works, the wealth of art, tradition and culture still survive along with the development of the era as the Living Monument. This makes the city of Cirebon very worthy to be called the City of Cultural Tourism or the City of National Heritage, maybe even as a World Heritage City. To be able to further enhance tourism in the city of Cirebon, contemporary tourism destinations need to be developed to serve the desires and tastes of tourists. Learn from other cities such as Yogyakarta which has Jl. Malioboro or Bandung which has Jl. Asia-Afrika, it seems that the city of Cirebon has the potential to be developed as well as the city of Yogyakarta and the city of Bandung. For this reason, there must be a policy from the city government to make the 'Karangwangi' corridor as the orientation of the morphological development of the city and the Landmark of the City of Cirebon.
\end{abstract}

Keywords: Heritage City, Cultural Tourism, Tourist Destinations, City Landmark.

\section{Introduction}

At the moment, if we look at the development of community activities in the city of Cirebon, it looks increasingly rapid. Various economic activities are growing well along with the better infrastructure in the city. Likewise, in the tourism sector, seen by the increasing number of tourist arrivals that have an upward trend. The development of the city of Cirebon as a tourist city, especially the city of cultural tourism, is in accordance with the Vision of the Regional Head of Cirebon City today, which is "one heart to realize the city of Cirebon as a creative city based on culture and history". Its mission, firstly, is to realize the quality of human resources (HR) of Cirebon city that is competitive, cultured and superior in all fields, secondly, to realize clean, accountable, authoritative and innovative governance, third, to improve the quality of public infrastructure facilities with insightful environment, and fourthly, creating conducive security and public order.

With an area of only approximately $38 \mathrm{~km}^{2}$, consisting of 5 (five) districts and 22 (twenty-two) villages, Cirebon city has almost no natural resources except historical cultural heritage which is quite complete and still well preserved today. is a relic of various historical periods. Among those who left the most heritage buildings were the period of the Islamic empire from the 15-16 century and the period of colonial rule in the 19th century [1]. In the period of the Islamic kingdom the historical cultural relics that exist such as; Keraton Kasepuhan, Kanoman Palace, Kacirebonan Palace, Keprabonan Palace, Gua Sunyaragi Water 
casteel, Sang Cipta Rasa Grand Mosque, Panjunan Red Mosque, Pejlagrahan Mosque, Jagabayan Mosque, Sunan Kalijaga site, Kejawanan Site, Ketandan Site, The tomb of Syekh Lemah Abang, The tomb of Sheykh Maghribi, Pangeran Drajat Site, and others. The existing palaces in the city of Cirebon are still active and continue to uphold their culture and customs.

In the colonial period the existing cultural relics such as; Residency Building, City Hall Building, Cirebon Regent's Office House, Kejaksan Station, Bank Indonesia Building, SMPN 1 Building, SMPN 14 Building SMPN 15 Building PDAM Parujakan Tower, Parujakan Station, Bunder Kebumen Building, PT.Cipta Niaga Building, Pasundan Church, Santo Yosef Church, Post Office Building, Bank Mandiri Building, PT.British American Tobacco Building, Kesambi Class 1 Penitentiary, and others. Besides the relics of the two historical periods, there are also Chinese cultural relics such as; Sam Cay Kong Tomb, Dewi Welas Asih Temple, Talang Temple and Winaon Temple.

Besides the historical cultural heritage in the form of cultural heritage buildings or tangible material above, Cirebon city also has many intangible relics, such as; art, religious activities, cultural activities, batik and culinary fabrics. Art in this case such as dance (Cirebon mask dance), music (tarling music), painting (glass painting) or carving (mask carving). Religious activities such as the adzan pitu are quite specific because they are not available elsewhere. Cultural activities such as; mauludan, grave pilgrimage, nadran and others [2]. Batik cloth from the city of Cirebon has a very distinctive batik motif, the motif 'Megamendung' which is an identical batik art work and has even become an icon of Cirebon batik. The uniqueness of the megamendung motif is not only its motif in the form of images resembling clouds with firm colors, but also the philosophical values contained in the motif. While for the culinary heritage of the city of Cirebon is known by many people as an area that has a lot of culinary maca, such as; jamblang rice, empal gentong, Lengko rice, tofu gejrot, satay bats, whipped noodles and so on.

Seeing the many potential historical cultural relics that exist in the city of Cirebon, both tangible and intangible, it is appropriate that the local government of the city of Cirebon makes all the richness of historical cultural heritage as a superior tourism potential in the future. It is rare to find areas in Indonesia, especially in West Java, which have the potential for cultural tourism as diverse as in the city of Cirebon. The potential of cultural tourism in the city of Cirebon can be considered comparable to that of the City of Yogyakarta in the Special Province of Yogyakarta or in the City of Surakarta in the Province of Central Java.

\section{Research Methods}

This study aims to identify elements of cultural heritage that exist in the city of Cirebon, both tangible and intangible, as well as the meaning or meaning contained therein and provide insight for stakeholders to be able to develop all the potential that exists so that it can be utilized in making urban tourism development policy [3]. The method used is a qualitative method, with ethnographic interviews, focus group discussions and direct interviews. The use of this method aims to get deeper data and contain meaning. Therefore, the qualitative method does not emphasize generalization (transferability), but rather emphasizes the meaning. This qualitative method uses descriptive research, where this descriptive research only describes something that is actually about a variable, and is not intended to test certain hypotheses, and the purpose of this descriptive study is to make a systematic or factual description or description of the facts, the characteristics and relationships between the phenomena studied. 


\section{Result and Discussion}

\subsection{The Concept of Tourism Development}

In the Cirebon City RPJMD document 2013-2018, the problem of tourism development in the city of Cirebon in general is a matter of cultural preservation. The proportion of funding for cultural preservation within the APBD is still very limited, while incentives and disincentives related to cultural preservation have never been done and the involvement of parties outside the government in cultural preservation is also still very minimal.

Whereas in the 2017 Cirebon City RIPPARDA, it is conveyed that the tourism development policy in the city of Cirebon, covers, first. Tourism destination development policy, second, tourism industry development policy, third, tourism institutional development policy, and fourth, tourism marketing development policy [4]. To be able to implement these policies a strategy has been formulated which is more concrete steps to realize the goals of tourism development in the city of Cirebon. Tourism development strategies consist of, tourism destination development strategies, tourism industry development strategies, tourism institutional development strategies, tourism marketing development strategies [5].

Even the West Java Provincial Government has also set up Cirebon City as a pilot city for tourism. The current Governor of West Java, Ridwan Kamil, said that Cirebon City is considered the readiest to be polished into a tourism city, because the tourism potential of Cirebon City is very large, from tourism objects, culinary sites, to other potentials. While in general the tourism objects in other regions in West Java Province are artificial tourism objects and natural attractions such as; landscaping, beaches, rivers, lakes, forests or mountains.

"Cirebon is perfect as a tourist destination," said Tourism Minister Arief Yahya on one occasion. Arief's comment was based on the great opportunity owned by the city of Cirebon as a tourist destination. At present two-thirds of tourists in West Java prefer to travel within their own province, this is different compared to Jakarta, with only 20 percent of the population traveling within the city. This means that 80 percent of tourists from Jakarta are a golden opportunity for the closest areas of Jakarta, such as Banten and West Java.

The tourism sector has a very important role for the city of Cirebon, this can be seen from the contribution of revenue which reached $40 \%$ of the Regional Original Revenue (PAD) of the City of Cirebon in 2018, this is equivalent to approximately eighty billion rupiahs, which is the largest sector in the city Cirebon, which contributed to the region's original income. While the number of tourist arrivals in 2018 recorded 1,072,365 tourists consisting of 1,062,891 domestic tourists and 9,474 foreign tourists. In 2020 the City Government of Cirebon is targeting tourist visits to reach two million tourists. With the existence of several transportation infrastructures that are currently in operation, such as; the toll road connecting Cirebon and Jakarta, the toll road connecting Cirebon and Surabaya, and the operation of the Kertajati Airport in Majalengka which serves flights to several cities in the country, it seems that efforts to increase the number of tourist visits to the city of Cirebon are not difficult to achieve. With all the potential it has and the support of a very adequate transportation infrastructure, the Cirebon city government must be able to optimize all available resources to achieve this target by increasing the ability of human resources in the field of tourism and its supporters, creating attractive tourist attractions, providing and adding adequate and adequate tourism support facilities and also prepare other infrastructure that supports good quality tourism [6]. 


\subsection{Cultural Tourism Development}

Although there are many cultural tourism potentials that are owned by the city of Cirebon, but it seems that they have not been able to be maximally utilized, cultural tourism calendars have not been routinely held, cultural attractions have not been widely held, tourism support infrastructure still needs to be improved and tourism support facilities need to be expanded so that tourists feel comfortable. Need a comprehensive and integrated effort in developing the city of Cirebon as a city of cultural tourism by involving many stakeholders, both from the elements of government, DPRD, the private sector, the community and also actors of art and culture, so that the city of Cirebon can become a leading cultural tourism city in West Java Province. The number of cultural potentials that is owned compared to other regions in West Java Province, makes the City of Cirebon has a huge opportunity to become a city of cultural tourism that is superior to others.

The City of Cirebon, which was founded on 1 Muharram $791 \mathrm{H}$, has experienced a fairly long period of historical development. In that period a lot of values and historical events that took place to form the characteristics of the city that exists today. Even so the remnants of the past in the form of architectural works, the wealth of art, tradition and culture still survive along with the development of the era as the Living Monument. This makes the city of Cirebon very worthy to be called the City of Cultural Tourism or the City of National Heritage, maybe even as a World Heritage City. With so many cultural heritages from various historical periods, there is no doubt that the superiority of the value of cultural heritage in the city of Cirebon has a very high value and must be preserved and maintained as part of efforts to preserve the nation's culture. The current Cirebon city development policy is aimed at enhancing development with the characteristics of Cirebon city as a tourist city with the advantages of traditional arts and culture as a characteristic and basic capital of development. In the Cirebon City Regional Spatial Plan (RTRW) for 2011-2031 the City Strategic Area Plan is set that accommodates the interests of the revitalization of the Keraton Area and the Sunyaragi Cave Area as tangible and intangible heirlooms [7].

From this policy, the local government has indirectly provided legitimacy and support for the efforts to restructure, preserve and develop areas that make it possible to be part of the enhancement and formation of local identity insight in the city of Cirebon. The image of the city of Cirebon as a tourist city that is cultured and Islamic as part of the preservation of cultural, religious and cultural values that has been taught by Kanjeng Sunan Gunung Jati as one of the Wali Sanga figures, makes this city has a unique value that is not shared by other cities in Indonesia.

\subsection{Karangwangi Corridor as Imaginary Axis of Cirebon City}

To be able to further enhance tourism in the city of Cirebon, contemporary tourism destinations need to be developed to serve the desires and tastes of tourists [8]. Current tourism objects in the city today are of many types and varieties, such as; city parks, squares, pedestrians, river banks, old buildings or even a road. Learning from other cities such as Yogyakarta, which has Jl. Malioboro or Bandung, which has Jl. Asia-Afrika, where tourism objects are now very well-known tourist destinations and crowded with tourists, it seems that the city of Cirebon has enough potential to be developed like the city of Yogyakarta and the city of Bandung. "Karangwangi" corridor, which is a combination of two roads, namely Jl. Karanggetas and Jl. Siliwangi, has a significant history in the formation of the city of Cirebon. 
In the development of the city's morphology, the Karangwangi corridor has always been an orientation for urban growth [9].

According to Sulendraningrat in Carita Purwaka Caruban Nagari Manuscript, it is said that the golden or golden age of Cirebon as a sovereign kingdom began from the appointment of Syarif Hidayatullah as the Sultan of Cirebon I until the end of the reign of the Sultan of Cirebon to II, namely Prince Agung or Panembahan Ratu namely from 1479-1649 M, During Syarif Hidayatullah, Cirebon, there were many political breakthroughs by establishing friendships with the sultanates in the archipelago, especially with Demak. At that time, the city center of Caruban Nagari was the center of political, religious, economic, maritime, cultural and infrastructure activities [10].

During the Syarif Hidayatullah it was recorded that Cirebon carried out massive construction, such as the Construction of the Pakungwati Palace / Kasepuhan Palace (1529), the Great Mosque of Sang Cipta Rasa (1498), markets, squares and other infrastructure. What is quite phenomenal is the construction of the road that connects the Pakungwati Palace in the area of weak to the village of mining (Gunung Jati), along approximately 5 kilometers, so that it can be passed by horse and cart, which I now call the Karangwangi Corridor, because it passes through two roads namely Karanggetas Road and Jalan Siliwangi. There was also built a guard post (Jagabayan), which is now known as the Jagabayan Mosque, for a traveler to rest before entering the city of the king / palace.

Many stories or myths that tell the corridor of this road, especially the road karanggetas, as long as the word brittle means broken easily tells that even very strong corals can get brittle in that place, so people who are arrogant despite having high knowledge can get brittle on the road. This myth starts from the story of Shaykh Magelung Sakti, a young knight with long hair, said to be looking for a cleric who can cut his hair. The knight is said to have come from the Middle East Baghdad State. The arrival of Shaykh Magelung Sakti to Cirebon because he heard that there were magic people in this area who could help cut his hair. There he met a scholar who was later known as Sunan Gunung Jati and it was there that he was cut his hair by the Sunan and the knight was willing to be his student. Since then the area has been named Karanggetas and the river or river that crosses the Karanggetas road is called Kali Sukalila, derived from the words like and Lillahitaala because Syekh Magelung felt like it and had willingly cut his hair.

In addition to the myth above, Karanggetas area is actually known as an area that is always wet and unstable (fragile), this is because Sunan Gunung Teak once made canals connected to the sea that functioned so that boats from the sea could be more inland, besides the canals could hold water the sea at high tide and also the area is unstable (fragile) because many traversed by horses and carts so easily damaged or brittle.

Seeing the history possessed in the Karangwangi Corridor, this could be a very interesting potential to be developed as a new tourist destination in the city of Cirebon. Karangwangi Corridor for the city of Cirebon can be developed as befits Malioboro for the city of Yogyakarta. Karangwangi Corridor (Karanggetas-Siliwangi) is indeed quite phenomenal for the people of Cirebon City, along the road corridor the heritage of the building is still intact. Call it from the north (Jalan Siliwangi), State Buildings (Residency), Cirebon City Hall, Kejaksan mosque, Panjunan mosque, Cirebon Regency Hall, Jagabayan Mosque (Karanggetas), Bala Salvation Temple (Winaon), Kanoman Palace with markets and buildings other buildings that have been destroyed, such as the luxurious Karang Kencana building/Canton Hotel/former Military Resort Command (Korem) which has now changed its face to a magnificent business complex 
The Karanggetas Road area has now turned into one of the prominent trade centers of Cirebon City. There are no more road failures like when the big cart transports hundreds of teak logs from the north. Along this road now stands the largest gold shopping center in the city of Cirebon and other economic activities. While the Jalan Siliwangi area is currently developing as the main office area in the city of Cirebon and also other supporting activities for the city.

\section{Conclusions}

It needs strong intention and commitment from the City Government, business people and also all components of society to be able to realize "Malioboro" in the city of Cirebon. There must be a policy or effort to be able to realize "Karangwangi", such as; good and beautiful physical arrangement of the road, traffic engineering to avoid traffic jams, pedestrian arrangement so that pedestrians feel comfortable, arrangement of green open spaces so that the area becomes shady, street furniture arrangement adds to the aesthetics of the road, structuring city lights as lighting, structuring billboards to be orderly and beautiful, and so on. If all of these efforts can be done, the city of Cirebon will have a new tourist destination that is not only able to bring in many tourists but also can increase the region's original income and welfare for its citizens.

\subsection{Acknowledgements}

Thank you to Ms. Retno Sunu and Ms. Triyuni for encouraging this submission, for her useful suggestions and critical comments so that this article will be better.

\section{References}

[1] U.-I. D. Center, "World Heritage-Cultural Landscapes," Descr. World Herit. Cult. Landscapes with a Bibliogr. based Doc. available UNESCO-ICOMOS Doc. Cent., 2009.

[2] K. Lynch, The image of the city, vol. 11. MIT press, 1960.

[3] P. Sabatier and D. Mazmanian, "The implementation of public policy: A framework of analysis," Policy Stud. J., vol. 8, no. 4, pp. 538-560, 1980.

[4] R. K. Judisseno, Aktivitas dan Kompleksitas Kepariwisataan. Gramedia Pustaka Utama, 2017.

[5] B. Antariksa, Kebijakan pembangunan sadar wisata: menuju daya saing kepariwisataan berkelanjutan. Intrans Publishing, 2018.

[6] C. R. Goeldner and J. R. B. Ritchie, Tourism principles, practices, philosophies. John Wiley \& Sons, 2007.

[7] J. Friedmann, Planning in the public domain: From knowledge to action. Princeton University Press, 1987.

[8] M. S. Prawiraredja, Cirebon: falsafah, tradisi, dan adat budaya. Perum Percetakan Negara, 2005.

[9] H. Shirvani, "The Urban Design Process Van Nostrand Reinhold," Co, New York, 1985.

[10] C. P. C. Nagari, "Karya Sastra Sebagai Sumber Pengetahuan Sejarah.” Bandung: Proyek Pengembangan Permuseuman Jawa Barat, 1986. 